\title{
橋桁に作用する砕波段波の流体力に関する実験的検討

\author{
Experimental Study on Fluid Force Acting on a Bridge Deck Subjected to \\ Plunging Breaker Bores and Surging Breaker Bores
}

\author{
庄司 学 $^{1}$. 平木 雄 $^{2} \cdot$ 藤間功司 ${ }^{3}$ ・鴫原良典 ${ }^{4}$
}

\author{
Gaku SHOJI, Yu HIRAKI, Koji FUJIMA and Yoshinori SHIGIHARA
}

\begin{abstract}
In this study, hydraulic experiments were carried out to clarify a tsunami wave load on a bridge deck, focusing on the variation of horizontal wave force effected by the change of deck position from still water level against the tsunami height. The values of averaged drag coefficient were calculated by using the measured maximum lateral force and tsunami velocity as 1.52 subjected to surging breaker bores and as 1.56 subjected to plunging breaker bores. In addition, the variation of horizontal wave force is more sensitive in the case that still water level is lower when a bridge deck is subjected to plunging breaker bores.
\end{abstract}

\section{1.はじめに}

2004年12月26日（UTC 00:58:53）に発生したインド洋 大津波はスマトラ島北西部のみならず，インド洋に面す る多くの国々の沿岸部を襲い，甚大な被害を与えた。ま た，2006年7月17日（UTC 08:19:28）にジャワ島南西部 において $M_{W}=7.7$ の地震が発生し，それに伴う津波によ って, ジャワ島南西部では死者 500 人を超える大災害と なった。最近の例としては，2010年2月 27 日（UTC 06:34:14）にチリ中部沖において $M_{W}=8.8$ の地震が発生 し, それに伴って発生した津波により数百人以上の犠牲 者が発生した。これらの津波被害の要因としては家屋等 の構造物の被災が挙げられるが, さらに, 港湾, 道路等 の社会基盤構造物が多数被災したことにより, 社会経済 活動に甚大な影響が発生した。それらの中でも橋梁構造 物は交通社会インフラの重要な要素であり, 被災時の緊 急活動や復旧活動を支える交通基盤として, 津波災害時 においても機能保持が強く求められる.

そのため, 橋梁構造物に作用する津波荷重評価は社会 的に契急な課題となっており，それらに関しては学術的 に未解明な点が多いため, 多数の研究者がこれらの研究 に取り組んでいる．実験的検討としては橋桁の縮尺模型 を用いた水理実験を通じて，片岡ら（2006）が橋桁に作 用する水平抗力に合田式（合田，1973）を適用すること の妥当性を検討しており，荒木ら（2007）は水平波力に 加えて鉛直波力を測定し, 波高に対する橋枌の位置との 関係を明らかにしている. Iemuraら（2007）及び杉本・

\begin{tabular}{|c|c|c|}
\hline $\begin{array}{l}1 \text { 正会員 } \\
2 \text { 学生会員 }\end{array}$ & 博 (工) & $\begin{array}{l}\text { 筑波大学准教授 } \\
\text { 筑波大学大学院システム情報工学研究科 } \\
\text { 構造エネルギー工学専攻 }\end{array}$ \\
\hline 正会員 & 工博 & 防衛大学校教授建設環境工学科 \\
\hline 正会員 & 博 (工) & 防衛大学校助教建設環境工学科 \\
\hline
\end{tabular}

運上（2008）は，橋枌模型に対する水理実験を行い，津 波浸水深と津波流速の関係や津波流速と津波波力の関係 について明らかにしており，特にIemuraら（2007）は緩 衝マウンド等の効果について検討している. 更に, 庄司 ら（2009）は橋桁の横移動という被害形態について相似 則を考慮した上で, 水理実験を実施し, 津波流体力と桁 移動との関係を定量的に評価している. 二井ら（2009） は実験より得られた水平波力と鉛直力から既往の設計式 に対する評価を行っており，中尾ら（2009）は実験と粒 子法による解析により, 津波作用時の橋梁周辺の流況を 詳細に評価している. 数值解析の観点からは, 五十里 · 後藤（2007）が粒子法による津波の遡上と汇濫流に伴う 桁橋の被災シミュレーションを行っており, 鴫原ら （2009）がStaggered leap-frog 差分法を適用した 3 次元数值 流体解析に基づいて橋桁の被災に関わる実験結果に対す る検証を行っている．しかし，津波の形態として巻き波 型及び砕け寄せ波型の砕波段波を想定した場合の砕波段 波の種類が橋桁の抗力係数に及ぼす影響や，橋桁に対す る津波の作用位置の変化が水平波力の感度に及ぼす影響 については明らかになっていない.

以上を踏まえ, 本研究では単径間 $\mathrm{RC}$ 桁橋に作用する 砕波段波を模擬した水理実験を実施し，巻き波型及び砕 け寄せ波型の砕波段波を受けた場合の津波流体力を，上 述した観点から評価することとする。

\section{2. 水理実験}

\section{（1）実験条件及び実験水路}

橋析へ作用する砕波段波としては巻き波型と砕け寄せ 波型の2種類をモデル化した．前者は河口部において橋 桁へ作用する砕波段波をモデル化したものであり，後者 は河口を遡上した後に橋桁へ作用する砕波段波をモデル 化したものである，実験条件を表-1に，実験水路を図-1 
表-1 実験条件

\begin{tabular}{|c|c|c|c|c|c|c|c|c|c|c|c|c|c|c|c|c|c|}
\hline \multicolumn{2}{|c|}{$\begin{array}{l}\text { CASE } \\
\text { 番号 }\end{array}$} & $\begin{array}{l}\text { 模型 } \\
\text { サイズ }\end{array}$ & $\begin{array}{c}\text { 橋桁模型設置位置 } \\
(\mathrm{mm})\end{array}$ & 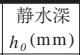 & $\begin{array}{l}\text { 桁下高 } \\
(\mathrm{mm})\end{array}$ & $\begin{array}{c}\text { 桁中心位置 } \\
h_{c}(\mathrm{~mm})\end{array}$ & \begin{tabular}{|c}
$\begin{array}{c}\text { 貯留水深差 } \\
(\mathrm{mm})\end{array}$ \\
\end{tabular} & \begin{tabular}{|c|}
$\begin{array}{c}\text { 貯水部水位 } \\
(\mathrm{mm})\end{array}$ \\
\end{tabular} & \multicolumn{2}{|c|}{$\begin{array}{l}\text { CASE } \\
\text { 番号 }\end{array}$} & \begin{tabular}{|l|} 
模型 \\
サイズ
\end{tabular} & $\begin{array}{c}\text { 橋桁模型設置位置 } \\
(\mathrm{mm})\end{array}$ & 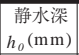 & $\begin{array}{l}\text { 桁下高 } \\
(\mathrm{mm})\end{array}$ & $\begin{array}{c}\text { 桁中心位置 } \\
h_{c}(\mathrm{~mm}) \\
\end{array}$ & $\begin{array}{c}\text { 貯留水深差 } \\
(\mathrm{mm})\end{array}$ & \begin{tabular}{|c}
$\begin{array}{c}\text { 貯水部水位 } \\
(\mathrm{mm})\end{array}$ \\
\end{tabular} \\
\hline \multirow{3}{*}{1} & 1 & \multirow{3}{*}{ 小 } & \multirow{3}{*}{5,500} & \multirow{3}{*}{40} & \multirow{3}{*}{10} & 18.5 & 80 & 422 & \multirow{3}{*}{9} & 1 & \multirow{3}{*}{ 大 } & \multirow{3}{*}{5,500} & \multirow{3}{*}{40} & \multirow{3}{*}{10} & 20.7 & 80 & 422 \\
\hline & 2 & & & & & 18.5 & 90 & 432 & & 2 & & & & & 20.7 & 90 & 432 \\
\hline & 3 & & & & & 18.5 & 103 & 445 & & 3 & & & & & 20.7 & 103 & 445 \\
\hline \multirow{3}{*}{2} & 1 & \multirow{3}{*}{ 小 } & \multirow{3}{*}{5,500} & \multirow{3}{*}{30} & \multirow{3}{*}{20} & 28.5 & 80 & 412 & \multirow{3}{*}{10} & 1 & \multirow{3}{*}{ 大 } & \multirow{3}{*}{5,500} & \multirow{3}{*}{30} & \multirow{3}{*}{20} & 30.7 & 90 & 422 \\
\hline & 2 & & & & & 28.5 & 90 & 422 & & 2 & & & & & 30.7 & 100 & 432 \\
\hline & 3 & & & & & 28.5 & 100 & 432 & & 3 & & & & & 30.7 & 114 & 446 \\
\hline \multirow[b]{2}{*}{3} & 1 & \multirow[b]{2}{*}{ 小 } & \multirow[b]{2}{*}{5,500} & \multirow[b]{2}{*}{20} & \multirow[b]{2}{*}{30} & 38.5 & 100 & 422 & \multirow[b]{2}{*}{11} & 1 & & & & & 40.7 & 110 & 432 \\
\hline & 2 & & & & & 38.5 & 110 & 432 & & 2 & 大 & 5,500 & 20 & 30 & 40.7 & 120 & 442 \\
\hline 4 & 1 & 小 & 5,500 & 10 & 40 & 48.5 & 130 & 442 & & 1 & & & & & 50.7 & 140 & 452 \\
\hline & & & & & & & & & 12 & 2 & 大 & 5,500 & 10 & 40 & 50.7 & 150 & 462 \\
\hline & & & & & & & & & & 3 & & & & & 50.7 & 160 & 472 \\
\hline & 1 & & & & & 18.5 & 40 & 382 & & 1 & & & & & 20.7 & 60 & 402 \\
\hline 5 & 2 & 小 & 1,500 & 40 & 10 & 18.5 & 48 & 390 & 13 & 2 & 大 & 1,500 & 40 & 10 & 20.7 & 70 & 412 \\
\hline & 3 & & & & & 18.5 & 60 & 402 & & 3 & & & & & 20.7 & 80 & 420 \\
\hline & 1 & & & & & 28.5 & 40 & 372 & & 1 & & & & & 30.7 & 70 & 392 \\
\hline 6 & 2 & 小 & 1,500 & 30 & 20 & 28.5 & 50 & 382 & 14 & 2 & 大 & 1,500 & 30 & 20 & 30.7 & 80 & 402 \\
\hline & 3 & & & & & 28.5 & 59 & 391 & & 3 & & & & & 30.7 & 90 & 414 \\
\hline 7 & 2 & 小 & 1,500 & 20 & 30 & 38.5 & 80 & 402 & 15 & 2 & 大 & 1,500 & 20 & 30 & 40.7 & 100 & 407 \\
\hline & 3 & & & & & 38.5 & 90 & 412 & & 3 & & & & & 40.7 & 110 & 422 \\
\hline 8 & 1 & 小 & 1,500 & 10 & 40 & 48.5 & 130 & 442 & 16 & 1 & 大 & 1.500 & 10 & 40 & 50.7 & 130 & 442 \\
\hline & & & & & & & & & 16 & 2 & 大 & 1,500 & 10 & 40 & 50.7 & 140 & 452 \\
\hline
\end{tabular}

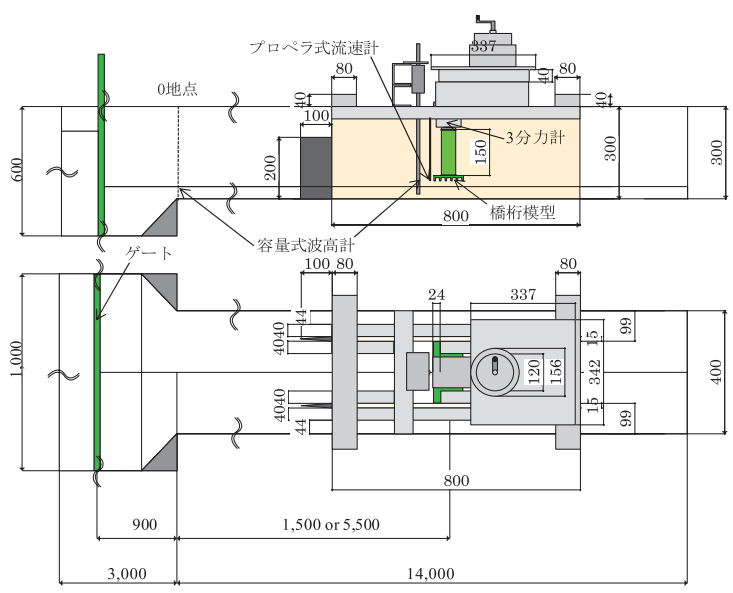

図-1 実験水路（単位 $\mathrm{mm}$ )

に示す．本実験では全長が $17 \mathrm{~m}$ ，幅 $0.4 \mathrm{~m}$, 高さ $0.3 \mathrm{~m}$ の開 水路を使用し，ゲート急開流れによって砕波段波を模擬 した。表-2, 図-2に実験で使用した橋栴模型の構造諸元 を示す．橋桁模型は2004年インド洋大津波の際にインド ネシアで実際に被災したLueng Ie Bridgeの桁長，幅員， 桁高を幾何学的に1/79.2（0.013），1/100（0.01）で縮尺 している. 実験に際しては, 静水深 $h_{0}$ を $40 \mathrm{~mm}, 30 \mathrm{~mm}$, $20 \mathrm{~mm}, 10 \mathrm{~mm}$ の 4 通りとした上で, 図-1中の 0 地点から $1,500 \mathrm{~mm}$ の位置における砕波段波を巻き波型砕波段波, 5,500mmの位置における砕波段波を砕け寄せ波型砕波段 波とそれぞれ定義した。従って表-1においてCASE1-1〜 4-1，9-1～12-3 が砕け寄せ波型砕波段波, CASE5-1～8-1, 13-1 16-2 が巻き波型砕波段波の津波作用を表わしてい る. その上で, 同一の静水深 $h_{0}$ で貯水部水位を変化させ ることで各ケースにおいて最大 3 段階の異なる波高の津 波を作用させている．計測したパラメータは橋桁模型前 面の津波流速，静水面を基準とした 0 地点及び橋桁模型
表-2 橋桁模型の構造諸元

\begin{tabular}{c|c|c|c|c|c}
\hline $\begin{array}{c}\text { 模型 } \\
\text { サイズ }\end{array}$ & 小 & 大 & $\begin{array}{c}\text { 模型 } \\
\text { サイズ }\end{array}$ & 小 & 大 \\
\hline $\begin{array}{c}\text { 桁長 } \\
L(\mathrm{~mm})\end{array}$ & 200 & 252.6 & $\begin{array}{c}\text { 床版幅 } \\
B_{1}(\mathrm{~mm})\end{array}$ & 95 & 120 \\
\hline $\begin{array}{c}\text { 床版厚さ } \\
T_{1}(\mathrm{~mm})\end{array}$ & 7 & 8.8 & $\begin{array}{c}\text { 桁厚 } \\
B_{2}(\mathrm{~mm})\end{array}$ & 5 & 6.3 \\
\hline $\begin{array}{c}\text { 桁高 } \\
T_{2}(\mathrm{~mm})\end{array}$ & 10 & 12.6 & $\begin{array}{c}\text { 桁間長さ } \\
B_{3}(\mathrm{~mm})\end{array}$ & 13 & 16.4 \\
\hline & & \begin{tabular}{c} 
縮尺 \\
\cline { 4 - 6 }
\end{tabular} & $1 / 100$ & $1 / 79.2$ \\
\hline
\end{tabular}

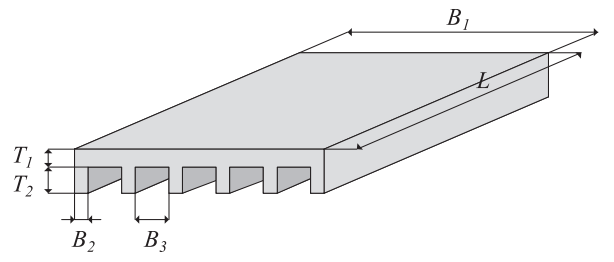

図-2 橋桁模型

前面の水位, 橋桁模型に作用する水平波力及び鉛直力で ある．津波流速についてはプロペラ式流速計（KENEK 製，VOT2-100-10），0地点水位及び前面水位については 容量式波高計（正豊工学実験装置製作所製, L-300), 水 平波力及び鉛直力については3 分力計（日計電測株式会 社製，Y102）を用いて計測している。データのサンプ リング間隔は $1 / 200$ 秒とし，ゲート開放から 20 秒間の計 測を行っている．全ての時系列データに対して，ある時 刻におけるデー夕について，そのデー夕と，その前後 10 データの合計 21 データを用いて移動平均を施している. なお，全てのケースについて橋桁模型を設置した状態で 実験を行った後, 橋桁模型を除した上で通過波の計測を 行い，5回の再現性の高いデータが得られるまで計測を 行っている. 分析に際しては水平波力は橋桁模型有りの 場合のデータを採用し, 津波流速及び前面水位について 
は橋桁模型を除した場合のデータを採用している.

\section{（2）実験におけるフルード数}

図-3には津波流速の平均である $v_{a v e}$ と浸水深の平均で ある $h_{\text {ave }}$ との関係を示す. 津波流速の平均 $v_{\text {ave }}$ はそのピー ク発生時刻から 1 ～秒間の信頼性の確保された区間の 平均である. 同じく前面水位のピーク発生時刻から 1 ～ 3 秒間の信頼性の確保された区間の平均である $a_{h_{\text {ave }}}$ に静水 深 $h_{0}$ を加算することで浸水深の平均 $h_{\text {ave }}$ を求めた。 図-3 の直線の傾きを本実験においてはフルード数 $F_{r}$ と定義す るが，それによるとフルード数 $F_{r}$ は $0.40 〜 0.93$ となった. フルード数の相似により，実橋に作用する津波流速は， 大模型において実験值の 8.9 倍の值になり，小模型にお いては実験值の 10.0 倍と解釈できる.

\section{3. 抗力係数の算出}

次式を用いて抗力係数 $C_{D}$ を算出した.

$$
C_{D}=\frac{F_{X}}{\frac{1}{2} \rho v^{2} A}
$$

水平波力の代表值として $F_{X}$ は橋林模型に津波が衝突した 瞬間の衝撃的な波力とし，津波流速の代表值として $v$ は 津波が流速計の感知部に衝突した瞬間の值とした。 $\rho$ は 水の単位体積質量, $A$ は橋桁模型の被水圧部面積である.

図-4には式（1）から算出される抗力係数の時系列を 示す. なお, 全 5 回の測定中, 水平波力 $F_{X}$ と津波流速 $v$ との間で，デー夕の立ち上がりにばらつきがみられたた め，全 5 回の中でそれらのばらつきが少ない 1 ～ 2 回分の データを用いた。更に，データの立ち上がり部において 式（1）の分母の津波流速 $v$ の数值が低くなると抗力係数

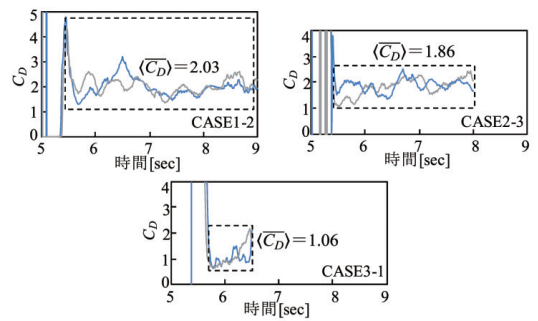

i) 小模型

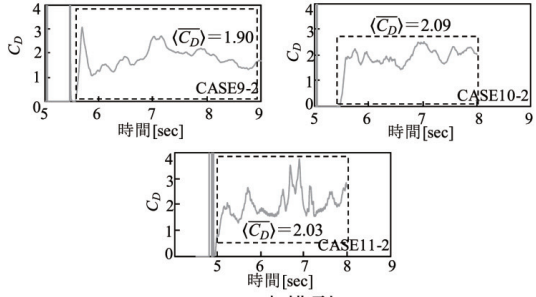

ii) 大模型
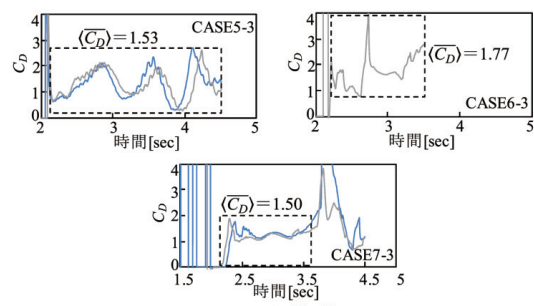

i) 小模型
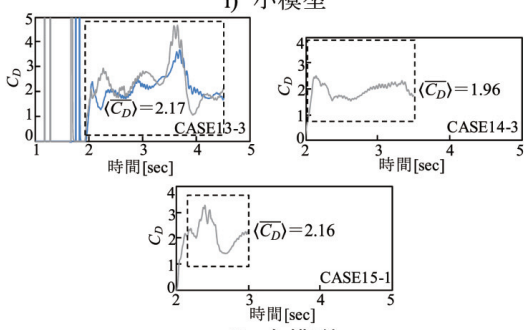

ii) 大模型

(a) 砕け寄せ波型䂶波段波

(b) 巻き波型砕波段波

図-4 抗力係数 $C_{D}$ の時系列 


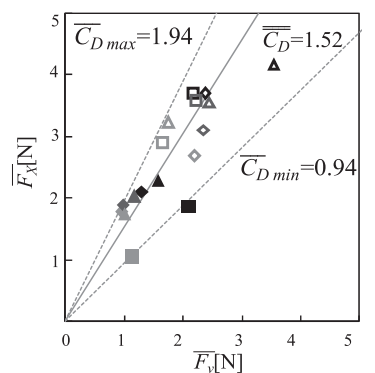

(a) 砕け寄せ波型砕波段波

砕け寄せ波型 巻き波型

- CASE1-2,9-2 CASE5-2,13-2 (静水深 $40 \mathrm{~mm}$ )

CASE2 $-1,10-1$ CASE6-1,14-1 (静水深 $30 \mathrm{~mm}$ )

CASE2-3, 10-3 CASE6-3,14-3

(静水深 $30 \mathrm{~mm}$ )

CASE3-2,11-2 CASE7-2,15-2

(静水深 $20 \mathrm{~mm}$ )

塗りつぶしは小模型 白抜きは大模型

図-5 $\overline{F_{X}}$ と $\overline{F_{v}}$ との関係

図-5には， $\overline{F_{X}}$ と $\overline{F_{v}}$ との関係を示す。その上で，図-5 に基づき，抗力係数 $\overline{C_{D}}$ を次式により算出した。なお， 図-5 中には, 抗力係数 $\overline{C_{D}}$ の最大值 $\overline{C_{D} \text { max }}$, 最小值 $\overline{C_{D}}$ min 及び平均 $\overline{\overline{C_{D}}}$ を直線で表した。

$$
\overline{C_{D}}=\frac{\overline{F_{X}}}{\overline{F_{v}}}
$$

図-5によると砕け寄せ波型において $\overline{C_{D}}$ は0.94 1.94の 間で変動しており, $\overline{\overline{C_{D}}}$ は 1.52 となっている. また, 巻き 波型において $\overline{C_{D}}$ は1.11 2.00の間で変動しており, $\overline{\overline{C_{D}}}$ は 1.56 となり，巻き波型の方が砕け寄せ波型より $\overline{C_{D}}$ はわず かに大きな值となった.このことは巻き波型が橋桁模型 に作用することで発生する水平抗力は, 砕け寄せ波型が 橋桁模型に作用することで発生する水平抗力に比べ，よ り大きな水平抗力となることを示している.

\section{4. 津波の橋桁に作用する位置とそれに伴って生 じる水平波力との関係}

静水深 $h_{0}$ を基準とした橋桁中心位置 $h_{c}$ を前面水位 $a_{h}$ の 平均值である $\overline{a_{h}}$ で除し, パラメータ $\gamma=h_{c} / \overline{a_{h}}$ を定義する. なお， $\bar{a}_{h}$ はデー夕の信頼性が保証された回数分の平均 值とする.この $\gamma$ は, 津波作用を受ける橋桁の水位に対 する相対的な位置を表す。次に, 水平波力 $F_{X}$ の平均值 である $\overline{F_{X}}$ を被水圧面積 $A$ で除し，それを静水圧相当の 圧力 $\rho g \overline{a_{h}}$ で除したパラメータ を次式のように定義した.

$$
\kappa=\frac{\overline{F_{X}} / A}{\rho g \overline{a_{h}}}
$$

この は津波作用による水平波圧が前面水位の高さ相当 の静水圧に対してどの程度の倍率となるかを示している.
図-6には $\gamma$ との関係を示す。図-6によれば，静水深 $40 \mathrm{~mm}$ (図中, ○印) では津波の下部が橋桁に作用する ため, 前面水位 $\bar{a}_{h}$ の高まり $+\bar{a}_{h}$ により生じる $\gamma$ の低下 $-\Delta$ $\gamma$ に対して水平波力の変化 $+\Delta \kappa$ がほとんど生じていな い. 静水深 $30 \mathrm{~mm}$ (図中, $\triangle$ 印) では津波の中間部が橋 桁に衝突するため, $\gamma$ の低下 $-\Delta \gamma$ に対して $+\Delta \kappa か ゙$ 生じ始 め, 静水深 $20 \mathrm{~mm}$ (図中, $\square$ 印) では津波の上部が橋桁 に衝突するため， $\gamma$ の低下- $\Delta \gamma$ に対して水平波力の高ま $\eta+\Delta \kappa$ が顕著となる. 以上の津波の橋桁に作用する位 置とそれに伴って生じる水平波力に関するメカニズムを 図-7に示す. 静水深が浅い $20 \mathrm{~mm}$ のケースでは津波の上 部の砕波部が橋桁に作用するため, $+\bar{a}_{h}$ に対して水平波 力 $\overline{F_{X}}$ の高まりがより大きくなると推察される.この傾向 は巻き波型において顕著になるが，これは砕波する直前 のエネルギーの高い部分が橋桁に衝突し， $\gamma$ の低下- $\Delta \gamma$ に対する $+\Delta \kappa$ の感度が砕け寄せ型と比較して高くなる ためである.

更に，図-6において合田式並びに朝倉式（朝倉ら， 2000）を併記することで，これらの波圧算定式との比較 を行っている. 合田式においては静水面から高さ $h_{c}$ で想 定される水平波圧 $p$ は次式で表すことができる.

$$
p=2.2 \rho g H \frac{3 H-h_{c}}{3 H}
$$

ここで，Hは静水面からの津波高さであり，本実験にお いては $\overline{a_{h}}$ に相当する. 同様に, 朝倉式においては, 非分 裂波を想定した上で静水面からの高さ $h_{c}$ で想定される水 平波圧 $p$ は次式により表すことができる.

$$
p=3 \rho g \eta \frac{3 \eta-h_{c}}{3 \eta}
$$

ここで, $\eta$ は遡上水深であり, 本実験においては $a_{h} に$ 相 当する. 式 (5)，（6）を変形し $H, \eta$ をそれぞれ $a_{h}$ に対 応させ, 水平波圧 $p$ が水平波力 $\overline{F_{X}}$ を被水圧部の面積 $A$ で 除したものに相当することを考えると，図-6中に併記す る式を導くことができる，なお，朝倉式についてはソリ トン分裂を考慮した式も併記した。

図-6によると, 砕け寄せ波型及び巻き波型における静 水深 $40 \mathrm{~mm}$ 及び $20 \mathrm{~mm}$ (小模型）の場合と巻き波型にお ける静水深 $30 \mathrm{~mm}$ (小模型) の場合には実験值が合田式 の下領域にあり，合田式による評価が可能となっている が，それ以外では評価が難しくなっている．合田式で想 定される波圧は防波堤に作用するものであり，桁下に空 間を有する橋桁の場合と境界条件が異なるためである. 次に, 朝倉式では非分裂波並びにソリトン分裂波の式の いずれの場合も静水深 $10 \mathrm{~mm}$ (図中, ○印) においてそ れらの上領域となり, 評価が難しくなっている. 朝倉ら 


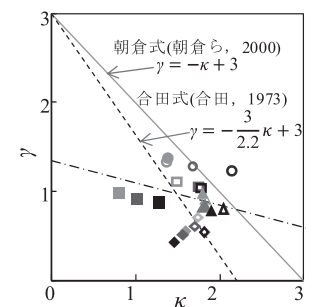

(a) 砕け寄甘波型砕波段波

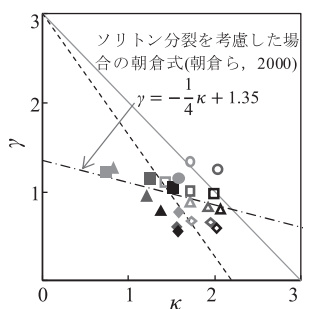

(b) 巻き波型砕波段波

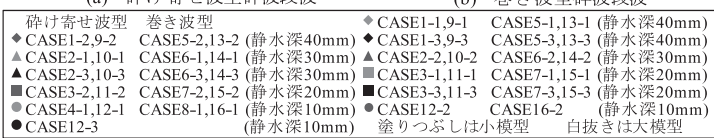

図-6 水平波力 $\overline{F_{X}}$ の評価

（2000）においては陸上に設置された構造物に対する津 波作用を模擬しており，この場合も本実験における境界 条件と異なるためである。このように，どちらの波圧算 定式においても危険となる場合があるため，橋桁に対す る波圧算定式の考案が急務である。

\section{5. 結論}

2004年インド洋大津波で被災した橋桁の縮尺模型を用 いて，巻き波型砕波段波及び砕け寄せ波型砕波段波の橋 桁への作用を模擬した実験を実施し，津波流体力の評価 を行った．以下に得られた主要な知見を示す。

(1) 水平波力の平均 $\overline{F_{X}}$ と津波流速 $v$ の 2 乗の平均 $\overline{v^{2}}$ 上り 求められる $\overline{F_{v}}$ により算出した抗力係数 $\overline{C_{D}}$ の平均 $\overline{C_{D}}$ は确け寄せ波型では 1.52 , 巻き波型では 1.56 となった, これより巻き波型が橋桁模型に作用することで発生す る水平抗力は，砕け寄せ波型が橋桁模型に作用するこ とで発生する水平抗力に比べ，ょり大きな水平抗力と なる。

（2）津波の橋桁に作用する位置とそれに伴って生じる水 平波力との関係を考察した結果，前面水位 $\bar{a}_{h}$ の高まり に比して水平波力 $\overline{F_{X}}$ の大きくなる割合は, 静水深 $h_{0}$ が 低くなるに従って大きくなり，その傾向は巻き波型に おいて顕著なものとなる。これは，巻き波型の方が砕 波する直前のエネルギーの高い部分が橋桁に衝突し， 砕け寄せ波型と比較して水平波力 $\overline{F_{X}}$ の感度が高くなる ためである。

（3）合田（1973）並びに朝倉ら（2000）を橋桁に対する 波圧算定式として適用することは，境界条件の違いか ら危険となる場合がある。そのため，桁下に空間を有 する橋梁構造物の境界条件に適した波圧算定式を考案 することが急務である.

謝辞：本研究は，国土交通省・平成 21 年度「道路政策の 質の向上に資する技術研究開発」(研究代表者, 九州工

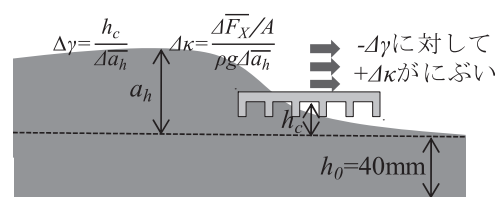

(a) 静水深 $40 \mathrm{~mm}$

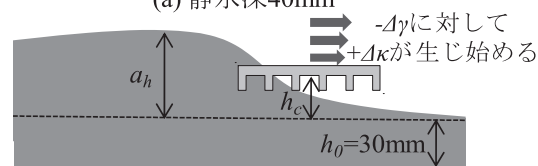

(b) 静水深 $30 \mathrm{~mm}$

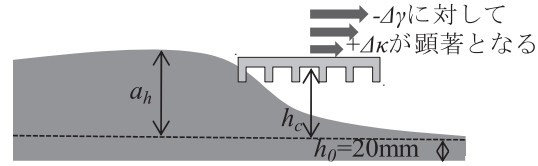

(c) 静水深 $20 \mathrm{~mm}$

図-7 水平波力の感度に関するメカニズム

業大学・幸左賢二教授）の助成を得て，その研究グルー プのご指導を得て実施されました．実験の準備及び実施 に際しては筑波大学大学院システム情報工学研究科の飯 高稔氏に多大なるご指導を頂きました。

\section{参 考 文 献}

朝倉良介・岩瀬浩二・池谷 毅 - 高尾 誠 - 金戸俊道・藤井 直樹・大森政則（2000）：護岸を越流した津波による波力 に関する実験的研究, 海岸工学論文集, 第47巻, pp.911-915. 荒木進歩・中島 悠・出口一郎・伊藤禎和 (2008)：河口付近 の橋梁に作用する津波流体力に関する実験的研究, 海岸工 学論文集, 第 55 卷, pp.866-870.

五十里洋行・後藤仁志 (2007)：津波汇濫に上る桁橋被災過程 の数值シミュレーション, 海岸工学論文集, 第 54 巻, pp.211-215.

片岡正次郎 - 日下部毅明 - 長屋和宏 (2006)：津波衝突時に橋 桁に作用する波力, 第 12 回日本地震工学シシポジウム, pp. 154-157.

合田良実（1973）：防波堤の設計波圧に関する研究，港湾技術 研究所報告, Vol.2, No.3, pp.31-69.

鴫原良典・藤間功司・庄司 学 (2009)：橋潹構造物に作用す る津波波力の数值計算, 地震工学論文集, Vol.30, pp.899904.

庄司 学・森山哲雄・平木 雄・藤間功司・鴫原良典・笠原 健治（2009）：巻き波砕波段波及び砕け寄せ波砕波段波の 作用を受ける橋桁の津波荷重評価,海岸工学論文集,第 56 卷, pp. $826-830$.

杉本 健・運上茂樹（2008）：津波による橋梁の被災メカニズ 厶に関する実験的研究, 第 11 回地震時保有耐力法に基づく 橋梁等構造の耐震設計に関するシシポジウム講演論文集, pp. $97-100$.

中尾尚史・伊津野和行・小林紘士（2009）：津波作用時におけ る橋梁周辺の流れと流体力に関する基礎的研究, 構造工 学論文集, 土木学会, Vol.55, pp.789-798.

二井伸一・幸左賢二・庄司 学・木村吉郎 (2009)：橋梁への 津波作用力に関する実験的検討, 構造工学論文集, Vol.55, pp.471-482.

Iemura, H., M. H. Pradono, T. Yasuda and T. Tada (2007) : Experiments of tsunami force acting on bridge models, 土木学会 地震工学論文集, Vol.29, pp.902-911. 